\title{
Te Hao Nui. The Great Catch. Object Stories from Te Manawa
}

Edited by Fiona McKergow and Kerry Taylor. Auckland: Random House New Zealand, 2011. ISBN 9781869797188

Reviewed by Sydney Shep

If biography is second only to fiction in the latest New Zealand bestseller lists, object biography too has achieved a renaissance. Eighteenth-century 'it-narratives' with their tales of 'babbling banknotes, canting coins, prosing pocket watches and soliloquizing snuffboxes' gave way in the nineteenth-century to fictionalized autobiographies of anthropomorphized talking books travelling, often tragi-comically, from one owner and one mise-en-scène to the next. ${ }^{1}$ The wildly popular commodity biographies of the nineteen-nineties such as Cod, Coffee, and Salt have today been joined by compelling tales of museum objects, whether rich and strange, quirky or mundane. Neil MacGregor's 2010 exposé of The British Museum's collections in the BBC 4 radio series, website, and subsequent book A History of the World in 100 Objects, Andrew's Moffat's recent Flashback: Tales and Treasures of Taranaki showcasing New Plymouth's Puke Ariki collections, or Fiona McKergow and Kerry Taylor's Te Hao Nui: The Great Catch suggest that the recovery and dissemination of object stories beyond display cases and exhibition walls is an essential, ongoing role for cultural heritage institutions.

Museums are charged with safeguarding historical memory; they are equally at pains to preserve and transmit their collections' stories, through time and across space, even when they diverge from accepted wisdom or present counter-narratives. As Arjun Appadurai states, 'from a theoretical point of view human actors encode things with significance, from a methodological point of view it is the things-in-motion that illuminate their human and social context.' ${ }^{2}$ To celebrate the fortieth anniversary of the opening of the Manawatu Museum, Palmerston North, forty objects from a collection of about 45,000 were painstakingly selected. Their stories were researched and written by a diverse team of contributors ranging from historians, curators, Māori scholars and descendants of the original donors. Framed by a short history of the institution from its origins in the Manawatu Philosophical Society Museum (1906) to the integrated Science Centre, Manawatu Museum and Manawatu Art Gallery (2000) and finally Te Manawa (2002), the volume reflects the background and interests of its co-editors; McKergow's work on the Dictionary of New Zealand Biography and experience as a social history curator is complemented by Taylor's longstanding involvement with the public history community. In explaining the book's origin and rationale, Te Manawa Museums Trust Chief Executive Steven Fox notes, 'people love objects, and they love to know the stories behind objects. They want to connect, they want to be moved and they want to remember; and more often than not, they want to learn more' (p.7). McKergow and Taylor acknowledge the difficulty of this enterprise. They characterize the process of deciphering 'signals from the past' as adopting both a zoom and a wide-angle lens. The material object can be scrutinized for clues about manufacture, transmission, use, and survival. Museum donation registers and ancillary documentation can fill in other information. Additional contexts, both historical and contemporary, can be extrapolated and overlaid, but the self-sufficiency of objects often requires what Neil MacGregor terms 'powerful poetic imagining' resulting in the 'necessary poetry of things.'

MacGregor, somewhat perversely and controversially, initially opted for radio to tell his one hundred object stories; he relied upon his listeners to imagine, not to see. By contrast, Te Hao Nui photographer Michael Hall has enabled each of the forty objects to speak visually and expressively. Furthermore, the editors are to be complimented for retaining the individual voices 
of the storytellers. Whether imagined reconstructions, essays in historical speculation, or academic writing, these stories are at once powerful and engaging. Open the book to any object and the all-engrossing nature of its narrative carries the reader away into many worlds: of the object, its particular history, supplementary archives including photographs, maps, family stories, donor memories, its contexts. For example, the story of a high-ranking Samoan woman's cloak - 'ie sina - interweaves curator and storyteller Sean Mallon's own heritage with that of its late-nineteenth-century guardian, Susana King. One version of the story suggests she received the cloak as payment for a debt while trading in Savai'i with her husband, a quondam employee of the writer Robert Louis Stevenson. Her daughters donated it to the museum in 1977, and her granddaughter in turn shared the family's memories with Mallon. Thanks to historian Bronwyn Labrum, Phoebe Pinfold's twelve-piece pine-needle tea set and table made for the New Zealand Centennial Exhibition in 1939-40 and bequeathed to the museum in 2003 by her granddaughter tells us as much about women's craftwork in rural Manawatu and its place in the public sphere as the value of social occasions, like afternoon tea, for the expression of domestic and civic virtue. Finally, regional councillor and local historian Jill White's bi-lingual tale of former Manawatu Museum Director Mina McKenzie, carver Te Aturangi Nepia-Clamp, and the whale-tooth pendant Te Rongorito is an eloquent testament to the animate lives objects possess even beyond their makers, owners, and storytellers.

This book's object-oriented approach to New Zealand history, society and culture is a powerful model and one as engaging for readers as museum-goers confronting those modern cabinets of curiosity, the collection drawers, primed for a voyage of self-discovery. It also reflects new museum practices in which, as the editors remark, 'objects enrich the stories we tell; stories enrich the objects we keep' (p.12). Museum display and labeling conventions seldom provide the whole story and rarely showcase the depth of knowledge present in an institution's curators and records. As exemplified in Te Hao Nui, storytelling involves and empowers communities and brings objects out of the storehouse and back into the public eye as well as back into public hands. Objects and their narratives are cradled in this codex's reading spaces, spaces that sit outside the institution, spaces that enable interactions at once private, intimate, and compelling.

Megan van Staden's design of the book facilitates a slow-paced, absorbing, reading experience. A graduate in Visual Communication from Massey University, she won the Publishers' Association of New Zealand 2012 Awa Press Young Designer of the Year Award for a portfolio that included Te Hao Nui as well as other notable Random House titles such as $Q$ and Eh: Questions and Answers on Language with a Kiwi Twist, Untamed, and The Parihaka Woman. Using a flexible grid, the combination of text, image, and layout complements each story and provides a parallel subtext. Overgenerous paragraph indents jar, however, and in a book devoted to the object, it is unfortunate that the very medium of communication, the typography, is nowhere given its own biography, even in the colophon. The fluid, contemporary, and exhibitional feel of Museo, designed in 2008 by Jos Buivenga and used for the titling and Māori texts, joins the classic and timeless body face Adobe Garamond in an otherwise beautifully designed work, one which should find pride of place, opened, on the reading desk, the coffee table, or the waiting room bench. ${ }^{4}$

Te Hao Nui offers a welcome glimpse into the 'great catch' of Te Manawa's treasures. The volume nets a multi-faceted array of objects across iwi, gender, class, and age groups, and reveals the breadth of an object's reach into local, national, and global communities. It demonstrates with verve and aplomb the possibility of telling history from the point of view of 
the object. And, in a world of information overload, it provides a salubrious human scale to the process of sense-making. McKergow and Taylor, along with their contributors, both past and present, surely echo MacGregor's assertion that 'all museums can rest on the hope - the belief that the study of things can lead to a truer understanding of the world. ${ }^{5}$

${ }^{1}$ Leah Price, How to Do Things with Books in Victorian Britain. Princeton and Oxford, 2012, p. 108.

2 Arjun Appadurai, 'Introduction: Commodities and the Politics of Value', in Arjun Appadurai, ed., The Social Life of Things: Commodities in Cultural Perspective, Cambridge, 1986, p.5. Quoted in Price, p.131.

${ }^{3}$ Neil MacGregor, A History of the World in 100 Objects, London, 2010, p.xv, xxiii, xvi.

${ }^{4}$ Personal communication with book designer, Megan van Staden, 14.08.12.

${ }^{5}$ MacGregor, p.xxv. 